\title{
The Application of Modern Education in General Biology Course
}

\author{
Wang Hongwei ${ }^{1}$, Yang Likun ${ }^{1}$, Xing Shaoying ${ }^{1}$ \\ ${ }^{1}$ The Key Laboratory of Zoological Systematics and \\ Application, College of Life Science \\ Hebei University, Baoding 071000, China \\ 906472733@qq.com
}

\author{
Cai Duanbo ${ }^{2}$, Wang Jianxia ${ }^{1}$, Shen Huichao ${ }^{1}$ \\ ${ }^{2}$ Institute of quality and technical supervision \\ Hebei University \\ Baoding 071000 \\ Bio2008@126.com
}

\begin{abstract}
With the development of global integration, more attention is paid to the modern teaching. The mutual fusion to modern teaching and biological course, bilingual teaching, multimedia teaching and the combination of general biology course, is an effective way to modernize the general biology course. This article summarizes the advantages of modern teaching, the connotation of bilingual teaching. Bilingual teaching in the educational reform in institutions of higher learning that is to carry out the important functions of the necessity. This paper expounds the institutions of higher learning to carry out the general biology lesson the significance of bilingual teaching and bilingual teaching of general biology course reform measures are put forward.
\end{abstract}

\section{Keywords—modern teaching; biology; bilingual; application}

\section{INTRODUCTION}

School education is the main way to carry out education activities and is also a way of inheriting civilization achievements and methods [1].Classroom teaching is the main form of school education, is the main way that teachers impart knowledge and skills. Classroom teaching situation is good or bad, directly affecting the quality of fostering talents [2]. General education curriculum is the key factor for implementing general education ideas and goals. Through the basis, integrity, comprehensiveness, extensiveness of knowledge, it aims to enable students broaden their horizons, avoid biased and foster the ability of independent thinking and judgment as well as social responsibility and sound personality. In other words, it aims to enlighten them to learn to behave. Physical Health, Mental Health, Nutrition and Health and other general education courses, are closely related to students living and health to educate students to study at the same time, but also pay attention to healthy lifestyles, develop healthy psychology and social adaptability. Modern teaching is not only the purpose of imparting knowledge and skills, but to improve the comprehensive quality of the people. It is significant and contributing for deepening the teaching reform, promoting the quality education and improving the quality of talent development to grasp the basic rules of modern teaching, study the modern education theories carefully and recognize the basic meaning and substantial characters of modern teaching [3].

\section{THE AdVANTAGES OF MODERN TEACHING}

Compared with traditional teaching, modernization teaching shows the superiority of its unprecedented:

\section{A. For the New Understanding of the Theory of Knowledge}

Compared with traditional teaching given priority to knowledge imparting and copy books' knowledge, modern teaching not only pays attention to basic knowledge firmly, also lays more emphasis on the cultivation of innovative consciousness. Constantly improve their own comprehensive strength and the good qualities of lifelong learning.

\section{B. Changes in Teaching Mode}

The traditional teacher-centered teaching injection that infusion book knowledge. While the modern teaching requires students to focus on the ability to grasp, apply and create knowledge for the purpose of the innovative teaching model; to instill knowledge-based, to the ability to cultivate students based.

\section{Different Teaching Environment}

The traditional teaching way is mainly about using blackboard, chalk, wall map to teach students, emphasizing the controlling function of the teacher in teaching. However, modern teaching way is by using modern information technology, communication technology and bilingual teaching, providing an ideal teaching environment for the process of teaching and education and new teaching mode.

\section{BILINGUAL TEACHING}

Globalization has a variety of characteristics; a significant feature is the "language", namely the national common language and the international common language."Wu ping [4] thinks that bilingual teaching is helpful to students to master two languages, understand and absorb in addition to the national culture of other country's culture, and it is conducive to students from two language thinking are available, and 
increase the ability to adapt to different nationalities and countries".

\section{A. The Connotation of Bilingual Teaching}

Longman Dictionary of Language Education and Application thinks bilingual teaching is a teaching way using a second language or foreign language to teach knowledge subject in school. System of Bilingual and Bilingual Education Encyclopedia thinks that bilingual teaching refers to the use of two languages in school, namely the use of two languages in school to teach science, maths, social science or humanities, etc."From the perspective of language teaching, bilingual teaching is the knowledge of a subject that teaches mother tongue in another language," said Professor Zhang Shaojie, deputy director of the National Basic Education Research Center of Northeast Normal University [5]. Chinese scholars $\mathrm{Lu}$ Danhuai pointed out that "bilingual teaching means using two languages as a medium of teaching language, which makes students through teaching language to achieve the ultimate goal of master two languages"[6].

\section{B. The Important Effect of Bilingual Teaching in the Educational Reform}

Setting up reasonable curriculum structure is the focus of the current teaching reform in our country. In the economic globalization, knowledge economization and highly information-based world, English has become an unquestionable international common language. The main carrier of information and culture is language. Its important role of information in social life has been received attention of the whole society.

\section{The Necessity of Bilingual Teaching in Colleges and Universities to Carry out}

\section{1) The Development of Economic Globalization}

\section{2) The Need to Cultivate Complex Senior Professionals}

Language not only is a tool for communication, but also can constantly change a person's outlook on life, values, world view, that has higher requirements on the students who have overall quality."How to cultivate high-level professional talents with high professional quality and familiarity with relevant international rules has become an important and urgent task for the institutions of higher learning, as well as to master foreign languages (especially English). Teaching reform is a strategic point "[7].

\section{3) Improve the Quality of English Teaching Requirements}

English is the common value of a discipline. The changes in college English Test Band Four and Six topic that makes English and international standards into a more important stage. Through the fact that "bilingual" carrier provides students with an English application of the situation to improve students' English ,such as listening, speaking, thinking ability and professional vocabulary to meet with the requirements including the social awareness of international cooperation, international exchanges and competitiveness export - oriented talents.
Han Lixin et al conducted a questionnaire survey on the impact of bilingual teaching [8]. They researched 301 students on the figure 1.The results supports the idea that bilingual teaching improves the quality of English.

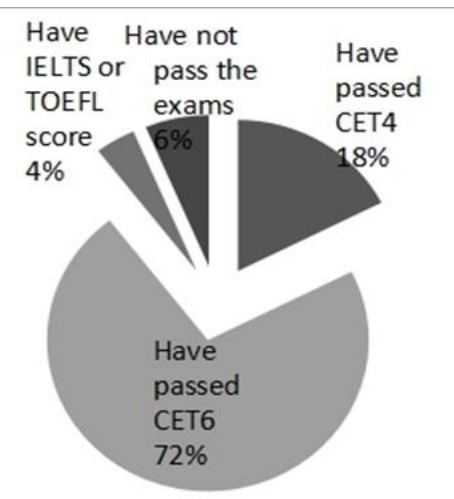

Fig. 1. A Questionnaire survey on the impact of bilingual teaching

Remark: Those who do not pass the exams have never bilingual teaching classes.

D. The Significance of Bilingual Teaching in Biology Liberal Studies in Colleges and Universities

A number of opinions the Ministry of Education promulgated in 2001 on strengthening undergraduate teaching work to improve the quality of teaching already have a basic determination of the range of bilingual teaching, that is in the high-tech fields of biotechnology, information technology and other professional, to meet the needs of China's accession to the WTO after the financial, legal and other professional, but also the first step is the implementation of bilingual teaching. Biology General Course Bilingual teaching is an effective way to improve the quality of teaching and the level of students' foreign language and the ability to apply. The 21 st century is a century of biology, and students of all professions need to learn biology-related general education courses. Bilingual teaching plays an important role in "cultivating college students' learning ability, creating perfect personality, enhancing competitiveness and improving overall quality" [9]. To lay the foundation for the realization of higher education and international standards, China needs to be in line with international standards, and higher education is not listed. Teaching in foreign languages is an effective means of understanding foreign culture, customs and connotations. Moreover, the mastery of foreign language on the economy, science and technology development also played a huge role in promoting.

\section{THE REFORM OF BILINGUAL TEACHING IN BIOLOGY LIBERAL STUDIES}

\section{A. Set up Bilingual Education Programs Scientifically}

With the process of biological research at home and abroad, many new creatures is found, the new genes have been cloned, and new protein has been extracted, there must be a solid knowledge of the English language, to better academic discussion. For difficult chapters, adjust the use of two languages, in order to achieve the best teaching effect [10]. 


\section{B. Strengthen the Construction of Bilingual Teachers in Colleges and Universities}

To cultivate excellent talents, bilingual teachers are the key, and what is most important is to strengthen the construction of bilingual teachers in colleges and universities. Schools can encourage and select those interested in bilingual teaching of graduate student training bilingual talents by means of this essay, for example, foreign language students choose a subject not majored in language as a minor course; Non professional students choose language as a minor courses, to graduate continuously enrich in the bilingual teaching staff [11].

\section{Optimize Teaching Methods}

Teachers teach properly handle and resolve conflicts expertise of English vocabulary, grammar, and other issues. Due to the limitations of professional vocabulary and the level of English, through reasonable teaching methods and teaching methods teachers mobilize the enthusiasm and initiative of students.

\section{Stimulate Students' Interest, Improve the Students' Confidence and Play the Initiative of Students}

In order to make the students easy to understand and enhance the popularity of content, strengthen the application of multimedia teaching methods, select the appropriate picture, and with animation, text, timely observation of student responses and adjust the teaching speed, enhance students confidence in professional English learning and play the students the ability to take the initiative to learn.

\section{E. Improve the Incentive Mechanism of Bilingual Teaching}

Bilingual teaching is more difficult than monolingual teaching. Whether in the lesson plans to prepare, class approach and correction work have a clear difficulty, and the overall quality requirements for teachers is also high. Therefore, establish a sound bilingual teaching reward mechanism.

\section{CONCLUSION}

The implementation of bilingual teaching is a systematic project, and it needs to rely on the entire educational environment and the cooperation of teachers and students [12]. Continuously improve, fill the gaps, overcome the difficulties, seek practical and effective bilingual teaching methods, through continuous efforts, bilingual teaching in the future will be into a healthy, good development track, for the nation to train useful talents and enhance the national competitiveness.

\section{ACKNOWLEDGEMENTS}

This research was supported by the demonstration center of provincial biological experimental teaching in Hebei University; Hebei ProvincialKey Laboratory of operating subsidy (item number: 14967611D); the practice project of undergraduate teaching quality and the "typical" teaching reform (2017-6 Biology science).

\section{REFERENCES}

[1] Galindo, Angelmiro; Moreno, Lina María. Formación bilingüe en licenciatura de Lenguas Modernas y comprensión lectora argumentativa Formation bilingue en Licence de Langues Modernes y comprehension lectrice argumentative Bilingual education in the Modern Languages teaching program and argumentative reading comprehension Formação bilíngue em licenciatura de Línguas Modernas e compreensão leitora argumentativa. Cuadernos de Lingüística Hispánica, 2014, 01 (23): 171-190.

[2] Quam, Carolyn; Creel, Sarah C.Mandarin-English Bilinguals Process Lexical Tones in Newly Learned Words in Accordance with the Language Context. 2017, 12(1): e0169001

[3] Gormally, Cara Deaf, Hard-of-Hearing, and Hearing Signing Undergraduates' Attitudes toward Science in InquiryBased Biology Laboratory Classes. CBE life sciences education.2017, 16(1) :37-45.

[4] van Berkel-van Hoof, Lian; Hermans, Daan; Knoors, Harry.Benefits of augmentative signs in word learning: Evidence from children who are deaf/hard of hearing and children with specific language impairment. Research in developmental disabilities , 2016,59,338-350.

[5] T Oltra, Miquel Molina; Sampietro, Agnese eaching Suggestions for the Use of Internet and the Interactive Digital Board in BilingualEducation Contexts. Digital education review,2015, 28, 1-18.

[6] Christoffels, Ingrid K.; de Haan, Annelies M.; Steenbergen, Laura; Two is better than one: bilingual education promotes the flexible mind. Psychological research-psychologische forschung, 2015, 79(3): 371379.

[7] Chen Liping; Wang Quanwei; Wang Jiqun Research and Practice in Electrocardiogram Teaching in English Mode in Chinese Medical Undergraduate. Journal of the american college of cardiology. 2014, 64(16S): C240- C240.

[8] Lixin Han, Shihui Yu.Reflections on the Reform of Bilingual Teaching in Colleges and Universities [J].Education Science, 2013,06:35-41.

[9] Galindo, angelmiro; moreno, lina maría. Formación bilingüe en licenciatura de Lenguas Modernas y comprensión lectora argumentativa Formation bilingue en Licence de Langues Modernes y comprehension lectrice argumentative Bilingual education in the Modern Languages teaching program and argumentative reading comprehension Formação bilíngue em licenciatura de Línguas Modernas e compreensão leitora argumentativa . Cuadernos de Lingüística Hispánica 2014, 23, 171-190.

[10] Santamaria, Kindra D.; Munoz, Maria L.; Atkins, Jenny L.A preliminary investigation into the application of processing instruction as therapy for aphasia in Spanish speakers. Journal Of Communication Disorders, 2013,46(4):338-350

[11] Deng, David; Bonniot, Daniel Teach our naming tool to be bilingual: Chinese name-to-structure conversion. Abstracts of papers of the american chemical society, 2013,245, 120-CINF.

[12] Baus, Cristina; Carreiras, Manuel; Emmorey, Karen When does iconicity in sign language matter? Language and cognitive processes.2013,28(3 SI): 261-271. 